\title{
MIR521-1 wt Allele
}

National Cancer Institute

\section{Source}

National Cancer Institute. MIR521-1 wt Allele. NCI Thesaurus. Code C82208.

The human MIR521-1 wild-type allele is located in the vicinity of 19q13.41 and is approximately 86 bases in length. This allele, which encodes MIR521-1 pre-miRNA, plays a role in the regulation of gene expression. Alteration in the expression of this gene is associated with development of prostate cancer. 